\title{
The Nexus Between Pilfering Menace and Crop Farmers' Income Shock: Evidence From Nigeria
}

\section{Theophilus Miebi GBIGBI}

Department of Agricultural Economics and Extension, Delta State University Asaba Campus, PMB 95074, Asaba- NIGERIA https://orcid.org/0000-0002-1335-723

$\varangle$ : gbigbitheophilusmiebi@yahoo.com

\begin{abstract}
Pilfering has a big impact on the crop farming industry and it is threatening the sustainability of the industry. To generate information that can be used to inform crop farmers on how to effectively mitigate pilferage on their farms, the study investigated the factors influencing pilferage and its effects on farmers' income in Delta State, Nigeria. A multistage sampling method was applied to choose respondents for the study. A sample size of 135 farmers were carefully chosen. The study data was analyzed with descriptive statistics, binary logistic regression, linear regression and one-way ANOVA. The findings showed that they had a mean age of 48 years and were mostly females who were also married. Majority of them were educated. The mean family size was 7 people and average farming experience of 11years with mean farm size of 1.15 ha. The result disclosed pilferage index of 0.68 , suggesting that $68 \%$ of farmers were victims of pilfering. The findings revealed that plantain has the highest proportion of the crops pilfered with $46.5 \%$ while cassava was the least with $11.5 \%$. The ANOVA result indicates a statistically significant difference $(\mathrm{F}=177.633 ; \mathrm{p}<0.000)$ in the mean of income losses to pilferage on the farms for the different selected crop types. Pilfering on farms was significantly influenced by age, farming experiences, educational status, farm size, household size, security, attractiveness of farm, employees with high number of dependents and distance or farm location. The findings showed that pilfering resulted to high cost of security, quitting farming activities, withdrawal from growing certain crops and reduction in output. Most of the respondents (78.5\%) did not use any form of measure to curb the menace of pilferage on their farms. It was recommended that tackling of pilfering on the farms should involve the synergy among government, community and the farmers.
\end{abstract}

Research Article

$\begin{array}{ll}\text { Article History } & \\ \text { Received } & : 08.03 .2020 \\ \text { Accepted } & : 09.07 .2020\end{array}$

Keywords

Pilfering on the farm

Income losses

Crop production

To Cite : Gbigbi TM 2021. The nexus between pilfering menace and crop farmers' income shock: Evidence from Nigeria. KSU J. Agric Nat 24 (1): 200-211. https://doi.org/10.18016/ksutarimdoga.vi.700483.

\section{INTRODUCTION}

Farming activities are expected to be rewarding to farmers as long as they enable them increase their productivity, earn increased income, enjoy high standard of living and as well as improve performance of basic civic responsibilities. The small scale crop farmers who constituted over 80 percent of the rural population are the major producers of the food consumed in Nigeria (Sabo et al 2017). These people depend on farm produce for food and income, and the extent to which they are supported and sustained by the farm output is a reflection of agricultural development. Unfortunately, some or all of these farm produce may be lost by farmers not only through pests and diseases but also by pilferage (or human pests). However, pilfering is much more dangerous than diseases and pests because it disturbs farmers emotionally and psychologically as well as causing serious economic losses to farmers (Bennett, 2016). This has tendency to discourage farming activities. It is interesting to note that pilferage on farms is an age old problem in Nigeria. In Africa, pilfering of farm produce has been identified as one of the challenges hampering the development of agriculture (Sabo et al 2017). Pilferage in farm causes serious damage to small-scale farmers who have neither the means to set up security measures nor the resources to weather losses and prompting some farmers to give up altogether. Worse still, the pilferage consequences not only apply to farmers that can bear the loss as far as lower profits are concerned, but also to consumers who may be forced to pay higher costs for goods (Mears et al 2007).

Similarly, Fafschamps and Minten (2003) argues that 
pilferage of crops can send shock waves to other members of community who may respond out of fear by abandoning farming. Graham (2010) found out that farm pilferage is the most discouraging and disincentive factor to agricultural investment in Caribbean nations.

Pilfering agricultural products in Ghana is a significant disincentive for irrigation agriculture, according to Inkoom and Nanguo (2011), where over $21.5 \%$ of irrigation farmers are the victims of farm pilfering during the dry season. Across the world, pilferage in farms is estimated to be as high as $\$ 5$ billion annually (Swanson et al 2000). In Australia, the estimated financial cost of farm pilferage as at 2002 was $\$ 72$ million with 68 percent of these loses being the value of loss or damage to farm while the rest is loss of income as result of pilferage (McCall 2003). Furthermore, Manning and Soon (2016) conceptualized pilfering as loss of resources, materials and produce on farms occasioned by deliberate and fraudulent removal by another person without any right to do so. McCaghy et al (2016) views pilfering as a clever way whereby a proportion of someone else's property is made away with usually on a continuous basis by the pilferer with a view to making the owner unsuspecting of the loss. Miller (2017) defined pilfering as a predatory felony in which a person deliberately takes someone else's property. According to Bunei et al (2013) pilfering on farms as a source of farm losses has long been known but its pestilence has recently increased to a level that should make producers and consumers alike uncomfortable. Pilfering is a social problem. In the recent past, pilfering was recognized on farms as a minor social problem and farmers did not bother much about it, though painful (Sabo et al 2017). Nowadays, even at the global level, pilfering in agriculture is so rampant that it touches and threatens all facets of agriculture. In the opinion of Bignon et al (2017), the means of rural survival have been threatened by losses through pilfering activities. The causes of these losses had in the recent past been mainly attributed to disease outbreak, poor management practices and poor soil type while pilfering had been greatly neglected. Therefore, pilfering of food crops is of immense importance to the farmers since their profit is gradually eroded and their produce/harvest greatly reduced where it is rampant. Thus its control is vital in order to improve the lot of food crop farmers. Farms are vulnerable to pilferage because of unique socio-demographic factors such as remoteness and distance between farms.

A literature search from developed nations shows that pilferage on the farm is linked to the specific nature of physical, social, geographical, and cultural environments of the farming communities (Anderson and McCall 2005; Barclay,2001; Barclay et al. 2001; Jones 2008; Mears et al. 2007). According to Barclay et al. (2001), unemployment is the most common social problems linked to pilferage on the farm. A study conducted in Australia by Anderson and McCall (2005) showed that isolated farmlands, larger farms with higher incomes, and proximity to urban centers were the greatest predictors of being a victim of various types of farm pilferage. Similar studies conducted by Mears et al. (2007) in the U.S. found that farm properties which are highly attractive, portable, and of high value, such as fruits and nuts, were more likely to experience pilferage. Barclay et al. (2011) found that farm pilferage was related to the number employees on the farm, with some farm workers being responsible for pilfering directly, or by-passing information to thieves for a fee.

Many farmers are becoming too old to actively engage in farming and the younger people are not actively involved in agriculture; therefore, food crop production has become drastically reduced causing food prices to escalate beyond the reach of the rural non-producers. This has resulted in some rural people pilfering food crop items from farms to make ends meet. Olusanya et al. (1995) in their study found causes of livestock pilferage to include greed $(66.66 \%)$, poverty $(59.16 \%)$, laziness $(29.17 \%)$, unemployment $(18.06 \%)$, bad company (16.6\%), inborn traits/kleptomania (11.11\%), lust (6.94\%); and wickedness (1.39\%). Similarly, they also identified the effects of pilfering on the farmers to include financial losses (95.83\%) and emotional disturbances (36.11\%). Olubanjo (1995) observed that pilfering lowers the standard of living of the private livestock farmers, reduces enterprise outputs as well as reduces substantially the income and profits realizable from livestock husbandry. Pilferage is fast becoming a serious problem to be researched on. It has been found to account for as high as $5 \%$ of the total cost to marketers and $4 \%$ of total loss of quantities handled (Anonguku 2005). The operational efficiency of marketers has been found to decrease with increasing pilfering rate with a correlation coefficient as high as 0.66. Profit per unit of commodity is also found to decrease with increasing pilfering rate and a correlation coefficient of -0.62 recorded (Banwo 1995). $\mathrm{He}$ also opined further that a single incident of pilfering might lead to withdrawal from farming activities. Pilfering is one of the biggest challenges faced by livestock farmers (Lesotho-South Africa Fence 2013). The rural area is one of the 'hotspot' areas where farm pilfering is conspicuous. Some farmers struggle to make a living as a result of pilferage on farms. It also threatens the sustainability of the crop farms which is the most important enterprise in the area, as some of the more experienced farmers are leaving the industry because of this problem (Magubane 2011; Lesotho-South Africa Fence 2013). Although there is a growing body of rural criminology and specifically criminology of food and agriculture (Barclay 2001; 
Bunei et al. 2013; Jones 2008; Mears et al. 2007 and Osborn 2015); much of it dwell on the nature, extent and cause of farm pilfering and less on the impacts of farm pilfering as experienced by farmers in Nigeria (Graham 2010; Fafschamps and Minten 2003 and Maloken).

It has been shown by observations that the pilfering of farm products is arguably the most pressing threat to the majority of farmers in Nigeria, as it deters and kills farmers' spirit and efforts, thereby not only affecting food production but also seriously impairing investment, creating jobs and reducing poverty (Bunei et al 2013).

Despite the significant losses associated with pilfering of farm products, the topic has received no attention from researchers in the study area. As such, a better understanding of the problem faced by the farmers could contribute more effective response strategies to mitigate pilferage in farms in the study area. This study is intended to provide valuable information to raise public awareness to combat pilfering on farms, thereby contributing to the development of the community.

There is dearth of research on the link between pilfering and farmers income shock in Delta State. Thus, no scientific evidence is available to advise farmers on the consequences and how to control pilfering on farms. However, even the available studies carried out elsewhere in Nigeria are also obsolete for policy issues. These research questions thus merit consideration: What are the socioeconomic characteristics of arable farmers in the study area? What is the level or extent of pilfering on the farms of the farmers? What is the amount of income loss to pilferage by crop farmers? What are the socioeconomic factors influencing pilferage on the farm? What are the effects of pilfering on farm income? What are the measures to curtail pilfering on the farm? This broad objective of this study was to analyze the Nexus between pilfering menace and crop farmers income shock in Delta State Nigeria. The specific objectives were to:

- describe socioeconomic characteristics of the farmers

- ascertain their level of pilfering on arable farms

- estimate the amount of income loss and the effects of pilfering on farm income

- examine the socioeconomic factors influencing pilfering

- identify measures of curtailing pilfering on farms.

\section{Hypothesis}

The following null hypothesis was tested

$\mathrm{H}_{01}$ : There is no significant difference in pilferage rate on crop types

\section{MATERIALS and METHODS}

The research took place in Delta State, Nigeria. The State is situated within longitudes $5^{\circ} 50^{\circ}$ and $6^{\circ} 45^{\circ}$ east of the Greenwich meridian and latitudes $5^{\circ} 25^{\circ}$ and $6^{\circ} 30^{\circ}$ north of the equator. It has three agricultural zones namely, Delta South, Delta Central and Delta North agricultural zones. Delta South agricultural zone comprises 6 local government areas (LGAs); Delta Central is made up of 10 LGAs; while Delta North zone is composed of 9 LGAs. The major source of livelihood of the people is agriculture, in a mixed cropping system. Cultivated crops include plantain, cassava, yam, okra, garden egg, cocoyam, maize, rice, potato and leafy and fruit vegetable crops. Tree crops like oil palm and rubber are also cultivated. Livestock mostly reared included poultry, goats and sheep.

To pick the respondents, multi-stage sampling was used. The first phase involved the purposive selection of the 3 agricultural zones; the second phase was a random choice of three LGAs from each zone to give 9 LGAs; the third phase was a random selection of three communities from each LGA to obtain 27 communities. Lastly, five farmers were carefully chosen from each community to obtain 135 respondents.

Primary data were collected with the use of structured questionnaire. The collected data were analyzed with descriptive statistics such as frequency counts, percentages and means derived from Likert type scale of high $(\mathrm{H})=3$, medium $(\mathrm{M})=2$ and low $(\mathrm{L})=1$ with a cut-off score of 2.00 .

Logistic regression model (binary logit) was used to determine factors influencing pilfering on the farm.

The implicit form of the model is expressed thus:

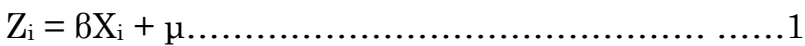

The explicit function of the model is stated as:

$\mathrm{Z}_{\mathrm{i}}=\mathrm{a}+\mathrm{b}_{1} \mathrm{X}_{1}+\mathrm{b}_{2} \mathrm{X}_{2}+\mathrm{b}_{3} \mathrm{X}_{3}+\mathrm{b}_{4} \mathrm{X}_{4}+\mathrm{b}_{5} \mathrm{X}_{5}+\mathrm{b}_{6} \mathrm{X}_{6}+\mathrm{b}_{7} \mathrm{X}_{7}$

$+\quad+b_{11} X_{11 \ldots . . . .2}$

Where:

$\mathrm{Z}_{\mathrm{i}}=$ Pilfering (dummy $1=$ pilfering on farm, otherwise $=0$ )

$\mathrm{X}_{\mathrm{i}}=$ vector of explanatory variables

$\mu=$ stochastic error term

$B=$ vector of the parameter estimates where the explanatory variables;

The definitions, measurement and descriptive statistics of the data used in the logistic regression analysis were shown in the Table1.

\section{Test for Multicollinearity}

It was desirable to fix the problem of multicollinearity between the variables before the selected variables were added to the model. This is because the presence of multicollinearity seriously affects the parameter estimate. To order for the logit specification of the model to be thoroughly clarified, the Variance Inflator 
Factor (VIF) and Hosmer-Lemeshow test were used as a multicollinearity measure.

The regression model was employed to estimate the effects of pilfering on farm income.

The model is implicitly specified as follows:
$\mathrm{Y}=\mathrm{f}\left(\mathrm{X}_{1}, \mathrm{X}_{2}, \mathrm{X}_{3}, \mathrm{X}_{4}, \mathrm{Xn}+\mathrm{e}\right)$

The definitions and descriptive statistics of the data used in the regression analysis were shown in the Table2.

Table 1. Descriptions of variables in the model

\begin{tabular}{|c|c|c|c|c|}
\hline \multirow{2}{*}{\begin{tabular}{|l|} 
Variables \\
Dependent Variable \\
\end{tabular}} & \multirow[b]{2}{*}{ Description } & \multirow[b]{2}{*}{ Measurement } & \multirow[b]{2}{*}{ Mean } & \multirow[b]{2}{*}{ SD } \\
\hline & & & & \\
\hline Pilfering & Pilfering on the farm & Dummy; 1 yes, 0 no & 0.7111 & 0.4549 \\
\hline \multicolumn{5}{|l|}{ Independent Variables } \\
\hline Age & Farmers' age & In years & 48 years & 7.1037 \\
\hline Experience & Farming experience & In years & 11 years & 4.3672 \\
\hline Gender & Genders of the farmers & Dummy; 1 male, 0 female & 0.6222 & 0.4866 \\
\hline Education & Farmers' education & Year of schooling & 2.7556 & 0.8328 \\
\hline Farm size & Farm size & In hectares & 2.8444 & 1.3151 \\
\hline Household size & People in the same roof & Number of people & 7 persons & 1.8038 \\
\hline Marital status & Farmers Married & Number of people & 0.5481 & 0.4995 \\
\hline Pilfering season & Time of occurrence & before maturity $=1$, maturity $=0$ & 0.8222 & 0.3838 \\
\hline Security measures & Security of farm & available $=1$, otherwise $=0$ & 0.4741 & 0.5012 \\
\hline Attractiveness of farm & attractiveness & attractive $=1$, otherwise $=0$ & 0.5630 & 0.4979 \\
\hline Employees high dependency ratio & Dependency ratio & Percentage & 67.1778 & 16.8770 \\
\hline location of farm & & $(\mathrm{km})$ & $4.8 \mathrm{~km}$ & 1.9078 \\
\hline
\end{tabular}

Table 2. Descriptions of variables in the model

\begin{tabular}{|l|l|l|l|}
\hline Variables & Description & Mean & SD \\
\hline $\mathrm{X}_{1}$ & high cost of security & 2.1778 & 0.8967 \\
\hline $\mathrm{X}_{2}$ & quitting farming activities & 3.4000 & 0.4917 \\
\hline $\mathrm{X}_{3}$ & withdrawal from growing certain crops & 2.1926 & 1.2063 \\
\hline $\mathrm{X}_{4}$ & discourage adoption of modern technologies & 3.2889 & 0.5713 \\
\hline $\mathrm{X}_{5}$ & Reduction in output & 2.7926 & 0.8295 \\
\hline $\mathrm{Y}$ & Income of respondent $(\mathrm{N})$ & 54803.70 & 19728.90 \\
\hline
\end{tabular}

For further analysis, analyses of variance (ANOVA) with post-hoc test for multiple comparison and independent sample $t$-test were used to observe the income loss and to know whether there is significant difference in the income loss of those arable crop farmers produce or not.

\section{RESULTS and DISCUSSIONS}

\section{Socioeconomic Characteristics of the Respondents}

Table 3 indicates that most $(60.0 \%)$ of the farmers were between age group of $30-49$ years with an average age of 48 years. This suggests that most of the farmers surveyed were middle aged. This means that they are still economically active, with a positive impact on growth. Age ratings are relevant for the study because physical capacity, productivity, and agility depend on age, thus determining the susceptibility or predisposition of the farmers to pilfering. This suggests that the farming population is still active and will therefore have the physical strength required in farming. This relatively small age will open them to technologies that can regulate pilferage as opposed to the older ones who generally expect social control measures to be respected. This result is consistent with the study by Zalkuwi et al. (2014), who indicated that in Guyuk Local government area of Adamawa State farmers were between 20 and 49, suggesting the active and productive age. Yahaha (2002) also reported that farmers aged 20 to 50 years are the most involved age group in farming practices

On farming experience, $54.8 \%$ of the respondents had between 6-10 years, while 26.7\% had between $11-15$ years of farming experience. The farmers that fell within the range of 1-5 years of farming experience represented $10.4 \%$ of the respondents and while only $8.1 \%$ of them had above 15years of experience. They had a mean farming experience of 11 years. The agricultural experience is used as a management capability indicator. The more experienced the farmer, the more he will take decisions on the farm. This findings indicate that most farmers have experience, meaning that they can make decisions that prevent or restrict pilferage and thus increase their income. This confirms Gbigbi (2011) findings that sweet potatoes are heavily dependent on farmers' experience, leading to improved managerial skills. 
Table 3. Socioeconomic characteristics of respondents (N=135)

\begin{tabular}{|c|c|c|c|}
\hline Variables & Frequency & Percentage & Mean \\
\hline $\begin{array}{l}\text { Age } \\
30-39 \\
40-49 \\
50-59 \\
\text { Above } 59\end{array}$ & $\begin{array}{l}16 \\
65 \\
46 \\
8\end{array}$ & $\begin{array}{l}11.9 \\
48.1 \\
34.1 \\
5.9\end{array}$ & 48 years \\
\hline $\begin{array}{l}\text { Farming experience } \\
1-5 \\
6-10 \\
11-15 \\
\text { Above } 15 \\
\end{array}$ & $\begin{array}{l}14 \\
74 \\
36 \\
11 \\
\end{array}$ & $\begin{array}{l}10.4 \\
54.8 \\
26.7 \\
8.1 \\
\end{array}$ & 11 years \\
\hline $\begin{array}{l}\text { Gender } \\
\text { Male } \\
\text { Female }\end{array}$ & $\begin{array}{l}36 \\
99\end{array}$ & $\begin{array}{l}26.7 \\
73.3\end{array}$ & Female \\
\hline $\begin{array}{l}\text { Educational level } \\
\text { No formal education } \\
\text { Primary education } \\
\text { Secondary education } \\
\text { Tertiary education }\end{array}$ & $\begin{array}{l}7 \\
43 \\
71 \\
14 \\
\end{array}$ & $\begin{array}{l}5.2 \\
31.9 \\
52.6 \\
10.4 \\
\end{array}$ & Secondary \\
\hline $\begin{array}{l}\text { Farm size } \\
\text { Less than } 1 \\
1-2 \\
\text { Above } 2 \\
\end{array}$ & $\begin{array}{l}82 \\
41 \\
12 \\
\end{array}$ & $\begin{array}{l}60.7 \\
30.4 \\
8.9 \\
\end{array}$ & 1.15 hectare \\
\hline $\begin{array}{l}\text { Household size } \\
1-3 \\
4-6 \\
7-9 \\
\text { Above } 9\end{array}$ & $\begin{array}{l}10 \\
36 \\
77 \\
12 \\
\end{array}$ & $\begin{array}{l}7.4 \\
26.7 \\
57.0 \\
8.9 \\
\end{array}$ & 7 persons \\
\hline $\begin{array}{l}\text { Marital Status } \\
\text { Never married } \\
\text { Married } \\
\text { Divorced } \\
\text { Widowed }\end{array}$ & $\begin{array}{l}22 \\
95 \\
8 \\
10\end{array}$ & $\begin{array}{l}16.3 \\
70.4 \\
5.9 \\
7.4\end{array}$ & Married \\
\hline
\end{tabular}

The majority $(73.3 \%)$ were women while $26.7 \%$ were men. This is indicative of the fact that women dominate food crop farming in the area. The study could be based on the fact that arable crops are generally grown by women who perform most farming activities, such as bush cutting, cultivation, planting and weeding. This is in line with the results of (Prakash 2003) report that women have been more interested in food production in India than their husbands. Ofuoku and Emuh (2009) were also of the view that the majority of arable crop production is carried out by women in their research.

With respect to level of formal education, most (52.6\%) of them had secondary education, $31.9 \%$ had only primary education and $10.4 \%$ had tertiary education. However, $5.2 \%$ of them had no formal education. This means that most have been educated. Education plays a significant role in increasing farmers' consciousness and affects approaches and techniques to discourage or curb pilfering. In general, education has been shown to have a positive effect on innovation adoption.

Thus well-educated farmers will learn good management skills and will be open to innovation in their farm sector, which is expected to increase their agricultural production activities and efficiency (Lemchi et al. 2003; Eze et al. 2006).

With regards to farm size of respondents, $60.7 \%$ had a farm size less than one hectare, $30.4 \%$ of them had farm size of between 1-2 hectares while only $8.9 \%$ had a farm size above 2 hectares. The average farm size in the study was 1.15 hectare. This shows that they were small scale farmers.

This could be explained by the fact that the small farms cultivated in most of the communities in Nigeria could also be due to land ownership arrangements that limit farmers growing large sections of land. This result confirms that the majority of Nigerian farmers are small scale farmers who cultivate less than 5 hectares of land (Arene and Anyeaji 2010; Oni and Fashogbon 2013).

The result of the household size of respondents indicated that $57.0 \%$ had household size ranging from 7-9 persons, 26.7\%had household size between 4-6 persons $16.3 \%$ had $7-9$ persons and only $7.4 \%$ of them 
had 1-3 persons members in their households. The average household size was 7 persons. This is prompted by the culture of housing and feeding a lot of relatives and polygamy that thrives in the study area. High family size in the region is an indicator of family labour available in the area. Which means that members of the family could assist in carrying out farming activities. This is because member of a family help in family enterprises in Africa, particularly in Nigeria. This finding confirm that of Ogunjimi (2001), which has large family size for the majority of farmers in Osun State.

Most (70.4\%) of the respondents were married, $16.3 \%$ were never married, $5.9 \%$ were divorced and $7.4 \%$ were widowed. The percentage of the married among them was high because of the high esteem the society accords them as responsible to embark on reasonable farming to cater for his/her households. This finding is in line with Gbigbi (2018), who held that married couples control the rural household.

\section{Level of pilfering on arable farms}

Table 4 indicates the level of pilfering on farms. It was observed that plantain and maize crops were adversely affected by high pilfering, as the means were above the cut-off score of 2.00. This is further confirmed by the pilfering index of 0.68 for all the crops, which implies that $68 \%$ of farmers were victims of pilfering on the farm. This scenario has the tendency to affect output of the farmers and eventually their income in the study area. Ibrahim et al (2017) identified maize to be one of the major crops easily pilfered in their study. According to a representative study conducted in rural Kenya in 2012, Bunei et al. (2013) found that virtually everybody (99\%) has been the victim of agricultural theft over a five-year period. Ceccato (2016) also notes that, over the last two years, 3 out of 10 farmers were targeted at some type of theft and half were targeted 2 or more times in Sweden. The common items stolen from farms in the developing country are the fuel, machinery, equipment, and other farm properties.

Table 4. Classification of level of pilfering on the farm

\begin{tabular}{|l|l|l|l|l|l|l|}
\hline Crops & High & Medium & Low & Mean & $\begin{array}{l}\text { Std. } \\
\text { Deviation }\end{array}$ & Decision \\
\hline Plantain & $120(88.9)$ & $10(7.4)$ & $5(3.7)$ & 2.85 & 0.45 & High \\
\hline Maize & $55(40.7)$ & $44(32.6)$ & $36(26.7)$ & 2.14 & 0.81 & High \\
\hline Yam & $20(14.8)$ & $51(37.8)$ & $64(47.4)$ & 1.67 & 0.72 & Low \\
\hline Cassava & $17(12.6)$ & $35(25.9)$ & $83(61.5)$ & 1.51 & 0.71 & Low \\
\hline
\end{tabular}

Cut-off score $=2.00(\geq 2.00=$ high pilfering $;<2.00=$ low pilfering $)$

Pilfering index $=0.68$

Amount of income loss to Pilfering by arable crop farmers

Table 5 indicates the income loss from plantain, yam, maize and cassava due to pilfering. It was observed that the average income losses from plantain was $\$ 94310.00(46.5 \%)$ while average income loss of maize and yam farmers are $\$ 52098.75(25.7 \%)$ and $\$ 33126.67(16.3 \%)$ respectively.

Table 5. Amount of income loss to pilfering among crop farmers

\begin{tabular}{|l|l|c|c|}
\hline Crops & $\begin{array}{l}\text { Amount } \\
\text { loss N }\end{array}$ & $\begin{array}{c}\text { Percentage } \\
\text { loss(\%) }\end{array}$ & $\begin{array}{c}\text { Ranking by } \\
\text { pilfering rate }\end{array}$ \\
\hline Plantain & 94310.00 & 46.5 & $1^{\text {st }}$ \\
\hline Maize & 52098.75 & 25.7 & $2^{\text {nd }}$ \\
\hline Yam & 33126.67 & 16.3 & $3^{\text {rd }}$ \\
\hline Cassava & 23454.00 & 11.5 & $4^{\text {th }}$ \\
\hline Total & 202989.42 & 100.0 & \\
\hline
\end{tabular}

Pilfering for cassava was the least $\$ 23454.00$ (11.5\%). Thus, plantain has the highest percentage of the crops pilfered with $46.5 \%$ while cassava was the least with $11.5 \%$. This could discourage any farmer from continuing his farm business. Recently, pilfering has become a major contributing factor to poverty in rural Nigeria (Anonguku et al. 2008). A single attack can wipe out all of the wealth and livelihoods of a household and experience has shown that recovery chances are quite minimal if not non-existent (Olubanjo 1995). This means that the loss of agricultural products by theft means that the household concerned loses both the value of its own use and the income it gained from the product sales. This work supported Claudia and Bainson (2016) research on the impact of pilfering on small business profitability.

\section{One way Analysis of Variance (ANOVA) on Income loss} to different crops

To check that whether income loss is same in the different crop types or not, one way ANOVA test was used. The results showed that at 5\% significance level, there was statistically significant difference in income loss between the different crop types as determined by one-way $\operatorname{ANOVA}(F(3,13)=177.63, p=.000)$, hence the null hypothesis was rejected and the alternate hypothesis was accepted that percentage income loss is different in the different crop types in the study area. This percentage income loss is consistent with Olusanya et al. (1995), who have established revenue losses as a result of pilferage for victims (Table 6).

From the results so far, it is revealed that there is significant differences between the percentage income 
losses of the different crop types as a whole in the study area. The Multiple Comparisons in Table 7 shows that the income loss level of each crop types differed from each other. The result of LSD post-hoc test also revealed that there is a significant difference between income loss and the cultivated crops by the farmers. Farming households are deprived of their livelihood income in the event of agricultural crimes when cattle, crops, machinery and instruments are looted from their farms (Grote and Neubacher 2016).

Table 6. Differences in percentage income loss in crop types

\begin{tabular}{|l|l|l|l|l|l|}
\hline & Sum of Squares & Df & Mean Square & F & Sig. \\
\hline Between Groups & 101378788666.20 & 3 & 33792929555.40 & 177.63 & .000 \\
\hline Within Groups & 24921481704.17 & 131 & 190240318.35 & & \\
\hline Total & 126300270370.37 & 134 & & & \\
\hline
\end{tabular}

Table 7. Multiple Comparison Table of the per Income loss of the different crop types

\begin{tabular}{|c|c|c|c|c|c|c|}
\hline \multirow[t]{2}{*}{ (I) crop types } & \multirow{2}{*}{\multicolumn{2}{|c|}{ (J) crop types Mean Difference (I-J) }} & \multirow[t]{2}{*}{ Std. Error } & \multirow[t]{2}{*}{ Sig. } & \multicolumn{2}{|c|}{ 95\% Confidence Interval } \\
\hline & & & & & Lower Bound & Upper Bound \\
\hline \multirow{3}{*}{ Maize } & Plantain & $-42211.25000^{*}$ & 3084.15562 & .000 & -48312.4455 & -36110.0545 \\
\hline & Yam & $18972.08333^{*}$ & 3331.26881 & .000 & 12382.0390 & 25562.1277 \\
\hline & cassava & $28644.75000^{*}$ & 3516.47845 & .000 & 21688.3168 & 35601.1832 \\
\hline \multirow{3}{*}{ Plantain } & maize & $42211.25000^{*}$ & 3084.15562 & .000 & 36110.0545 & 48312.4455 \\
\hline & Yam & $61183.33333^{*}$ & 3331.26881 & .000 & 54593.2890 & 67773.3777 \\
\hline & cassava & $70856.00000^{*}$ & 3516.47845 & .000 & 63899.5668 & 77812.4332 \\
\hline \multirow{3}{*}{ Yam } & maize & $-18972.08333^{*}$ & 3331.26881 & .000 & -25562.1277 & -12382.0390 \\
\hline & plantain & $-61183.33333^{*}$ & 3331.26881 & .000 & -67773.3777 & -54593.2890 \\
\hline & cassava & $9672.66667^{*}$ & 3735.09795 & .011 & 2283.7520 & 17061.5814 \\
\hline \multirow{3}{*}{ Cassava } & maize & $-28644.75000^{*}$ & 3516.47845 & .000 & -35601.1832 & -21688.3168 \\
\hline & plantain & $-70856.00000^{*}$ & 3516.47845 & .000 & -77812.4332 & -63899.5668 \\
\hline & Yam & $-9672.66667^{*}$ & 3735.09795 & .011 & -17061.5814 & -2283.7520 \\
\hline
\end{tabular}

*. The mean difference is significant at the 0.05 level.

Relationship between the socioeconomic characteristics of farmers and pilfering on farms

The result of the logistic regression analysis is presented in Table 8. All the respective Variable Inflationary Factors (VIF) of the Collinearity statistics are between 1.039 and 3.488; an indication that there was no multicollinearity among variables. The output of Hosmer- Lemeshow test shows that the value of the chi-square is 1.417 with a significance value of 0.994 which is greater than 0.05 suggesting that the data for the logit model fits well (Table 9).

The results showed that age, farming experience, education, household size, security, employees high dependency ratio and distance or location of farm were significant at $5 \%$ level, while farm size and attractiveness of farm were significant at $1 \%$ level. The coefficient of age was significant but bore a positive sign. This means that a unit increase in age would most likely lead to a unit increase in the level of pilfering on farms because the old may feel reluctant to use the best security strategies to prevent pilfering on the farm based on financial implications. This could create a gap for pilfering on farms usually carried out by young people who find it difficult to involve in farming due to the tedious nature. In an attempt to make ends meet, they go about people's farm for pilfering. This agreed with findings of van Kesteren et al. (2014). Farming experience had significant influence on pilfering on the farm. A unit increase in farming experience will most likely lead to a unit decrease in pilfering on the farm because the more experience a farmer has the more his knowledge on strategies used by farm thieves and device counter alternative measures of pilfering prevention and vice versa. With experience, which is the best teacher, the farmer will make him/herself available at all cost to minimize pilfering on the farm to increase output. Farming involves a lot of risks and uncertainties; therefore to be competent enough to handle all the vagaries of agriculture, experience count. This result is in consonance with Ebojei et al. (2011) findings on factors influencing produce pilferage in Kogi State.

Formal education also had significant negative relationship with pilfering on the farm. A low level of formal education increases the chances of pilfering on the farm because of the inability of the farmers to acquire adequate information and best strategies to curb the farm risk. Education plays a key role in awareness-raising among farmers and influences the implementation of strategies and methods to avoid or restrict pilferage. Largely, formal training has been shown to have a positive impact on adopting innovation (Ebojei et al. 2011). In addition, lack of education induces unemployment and proscribes adequate wages. This could lead to the use of pilfering as livelihoods (Muller 2016; Melkonyan 2016). 
Table 8. Logit regression result of factors influencing pilfering on the farm

\begin{tabular}{|l|l|l|l|l|l|l|}
\hline Variables & B & Std. Error & Wald & Sig. & Exp(B) & Vif \\
\hline Age & .669 & .259 & 6.702 & .010 & 1.953 & 3.488 \\
\hline Farming experience & -.359 & .187 & 3.703 & .054 & .698 & 2.532 \\
\hline Gender & -1.217 & 1.421 & .733 & .392 & .296 & 1.314 \\
\hline Education & 2.153 & .853 & 6.368 & .012 & 8.611 & 1.366 \\
\hline Farm size & -5.655 & 1.720 & 10.814 & .001 & .004 & 2.484 \\
\hline Household size & -1.905 & .819 & 5.406 & .020 & .149 & 2.462 \\
\hline Marital status & 2.237 & 2.016 & 1.231 & .267 & 9.365 & 1.344 \\
\hline Pilfering season & -.904 & 1.637 & .305 & .581 & .405 & 1.366 \\
\hline Security & 2.105 & 1.029 & 4.182 & .041 & 8.209 & 1.052 \\
\hline Attractiveness of farm & 2.298 & .943 & 5.938 & .015 & 9.956 & 1.091 \\
\hline $\begin{array}{l}\text { Employees with high number } \\
\text { dependents }\end{array}$ & .212 & .081 & 6.948 & .008 & 1.237 & 2.227 \\
\hline Distance or location of farm & .787 & .382 & 4.243 & .039 & 2.198 & 1.039 \\
\hline Constant & -4.235 & 11.398 & 4.521 & 0.033 & .000 & \\
\hline Cox \& Snell R & & & & & \\
\hline Nagelkerke R & 0.602 & & & & & \\
\hline -2Log likelihood & 0.860 & & & & & \\
\hline
\end{tabular}

Farm size was found to be significant and positively related to pilfering of farm at $1 \%$ probability level. This shows that farmers with large farms are more prone to pilfering than those who are small-scale farmers. This conforms to a priori expectations as households with large farm size are more likely to have increased pilfering when compared with households that are constrained by land availability because the greater the farm size, the more the harvest and the more the harvest the less likely a farmer is able to keep an eye on his produce. This is followed by the fact that big farms appear to be more victimized than smaller farmers (McCall 2003; Mears et al 2007). The term "large farm" has widely differed from one country to another, but Bunei et al. (2013) has also confirmed this observation in Kenya.

Household size also had a significant influence on pilfering. However, the coefficient bore a negative sign. This means that a unit increase in household size would most likely result to a unit decrease in pilfering on the farm and vice versa. This is attributable to the fact that a large household could make himself or herself available for farm pilfering prevention. Again, farmers with large household sizes are always busy with farming activities to be able to cater for the members of their households.

The coefficient of security also had a significant influence on pilfering on the farm. However, the coefficient bore a negative sign. The implication is that the more security measures used for the farm safety, the lower the chances of pilfering and vice versa. So, a farmer's safety measures decides whether his farm may be exposed to pilferage, and when the thieves know that a farmer has adequate and sound safety measures, they search elsewhere. However, as reported, less safety measures are being used by farmers (Jones 2008). This confirms Odekina's (2009) findings concerning the effects of pilferage on arable farmers in Kogi State Nigeria. The decision to pilfer would be predisposed in areas where there is little monitoring and access to goods that can be easily move is high (Palmary, 2001).

The coefficient of attractiveness of farm had a significant and positive relationship with pilfering. This means that the use of improved varieties would most likely increase the farmers risk of pilfering on the farm because farmers who use hybrid varieties of crop in a local setting where most farmers use local variety would have their produce prone to pilfering. This can reduce farmers morale and output. Mears et al. (2007) findings in America similarly show a higher risk of pilfering of highly desirable, compact and profitable farm properties.

The employee's high dependency ratio had a significant influence on pilfering. However, the coefficient bore a positive sign. The implication is that a unit increase in number of dependents, the higher the chances of pilfering on the farm for survival of the fittest and vice versa. Thus, some farm workers are predisposed to steal by the pressure to provide for their dependents with the low pay. The result is in line with Barclay (2001), who found that pilfering in farms was correlated with the numbers of farm workers, with some farm workers getting direct involvement or by supplying the villains with information for a fee.

The coefficient of distance or location of farm was negative and significant. This suggests that the closer the farm, the chance of pilfering will increase. Donnermeyer et al. (2011) indicates that crop theft most likely happens in isolated and remote areas as criminals may steal at low risk. Also small-scale 
farmers in many developing countries can be found in various locations over longer distances away from their farms. These farmers may therefore be affected further. A research by Anderson and McCall (2005), conducted in Australia, found the primary predictors of becoming a target of the different form of farm theft were isolated farmlands, larger farms with greater incomes and the closeness to urban centers.

Table 9. Hosmer and Lemeshow test

\begin{tabular}{|l|l|l|l|}
\hline Step & Chi-square & Df & Sig. \\
\hline 1 & 1.417 & 8 & 0.994 \\
\hline
\end{tabular}

\section{Effect of pilfering on farm income}

The results of the linear regression analysis of the effect of pilfering on income loss from crop types of the respondents' are presented in Table 10. The coefficient of determination, R-Square, is 0.580 which implies that explanatory variables accounted for $58 \%$ of the variation in the dependent variable (income losses). The Adjusted R-Square of 0.564 is reasonably close to the value of the R-Square (0.580), implying that the correlation between independent variables included in the regression and the dependent variable $\mathrm{Y}$ was quite good. The Durbin-Watson statistic of the analysis is 0.943 which indicates the absence of autocorrelation. The F-Value is 35.628 , and is statistically significant (sig. 0.000). This is an indication that the combined effect of independent variables on the dependent variable is very significant. All the respective Variable Inflationary Factors (VIF) of the Collinearity statistics are between 1.086 and 2.696; an indication that there was no multicollinearity among variables. The results of the regression analysis in Table 10 showed that 4 variables had a significant influence on the income losses to pilfering by the respondents. These variables were high cost of security, quitting farming activities, withdrawal from growing certain crops and reduction in output.

The findings showed that high cost of security by respondents had a negative and statistically significant influence ( $\mathrm{sig}=0.000, B=0.250$ ) on income losses with all other factors held constant. The implication is that a unit increase in cost of security will correspond to a 0.250 units increase in income losses from pilfering. A possible explanation for this could be that the financial status of the farmers hinders them from engaging competent security apparatus. This has significant implications for security policies. Barclay (2001) also found that farm pilfering is common and costly for farmers in the area of study.

Withdrawal from growing certain crops had a negative and statistically significant effect on income losses from pilfering ( $\mathrm{sig}=0.009, B=0.248$ ) with all other factors held constant. This infers that a unit increase in the withdrawal from growing certain crops variables would result to a 0.248 units increase in income losses from pilfering. The reason for this effect may be the fact that since the expected returns is not realized with the tedious nature of the crop types involved will necessitate the farmers to shift to less strenuous crops that are free from pilferage. This finding is consistent with the work of (Banwo 1995; Odekina 2009) who stated that pilferage can deter a farmer by a single incident. Vincent et al. (2014) reported that higher pilfering rates are likely to adversely affect economic conditions, as the prevalence of pilfering in an area discourages farm enterprises. It can lead to a catastrophic economic downturn through negative income shocks.

Quitting from farming activities by respondent, also had a negative and statistically significant effect on the income losses from pilfering ( $\operatorname{sig}=0.000, B=0.498$ ) with all other factors held constant. This suggests that a unit increase in quitting rate would result to 0.498 units increase in income losses to pilfering. This may be due to the fact that such farmers might have spent huge amount of income without realizing maximum profit and satisfaction wherein the work done is zero which amount to discouragement and quitting the farm business. The farmers quitting tendency must have been motivated by the cost of acquired relevant training and skills over the years to generate increase output and income with the application of modern technology to improve on the quality of the farm resulting to attraction of pilferage. The research reported that they will not actually cultivate these crops because of the high susceptibility rate of the crops (Odekina 2009).

Kehinde et al. (2015) opined that farmers could face unprecedented challenges as a result of significant income loss. It could negatively affect the farmers and their families' current and future incomes and wellbeing. This is because many farmers retain dependents who are not even immediate relatives, which could lead to a reversal. Pilfering threatens the sustainability of the livestock industry, which is the largest enterprise in the area, as a consequence of the problem some of the more experienced farmers leave the industry (Magubane 2011; Lesotho-South Africa Fence 2013).

The coefficient of reduction in output had a negative and statistically significant effect on income losses from pilfering ( $\mathrm{sig}=0.006, B=0.250$ ) with all other factors held constant. The results show that a unit increase in the reduction in output by the respondents from farming will increase income losses from pilfering by 0.250 units with all other factors held constant. The primary idea of farm business is profit maximization through good harvest. This is the factor that will caused the farmers to remain in the crop industry. The effortlessness nature from the farm through pilfering will affect farm labour availability and food security as 
well as food prices to escalate beyond the reach of the rural non-producers. With a rising pilferage rate with a correlation coefficient of up to $-0,66$, the working output of respondents decreased. Profits per unit of commodity are decreased as the pilferage rate increases and a correlation coefficient of -0.62 is registered (Banwo 1995). The consequences of pilfering on farms include a loss of household income and an enforced decrease in own consumption and in the sale of farm produce. Alarmingly, pilfering has reduced the capacity of the farmers to invest in their children human capital development and this also affects household's food security and nutritional status (Manu et al. 2014).

Table 10. Regression result for estimation of income losses to pilfering

\begin{tabular}{|l|l|l|l|l|l|l|l|}
\hline \multirow{2}{*}{ Model } & \multicolumn{2}{|l|}{$\begin{array}{l}\text { Unstandardized } \\
\text { Coefficients }\end{array}$} & $\begin{array}{l}\text { Standardized } \\
\text { coefficients }\end{array}$ & T & Sig. & \multicolumn{2}{l|}{$\begin{array}{l}\text { Collinearity } \\
\text { Statistics }\end{array}$} \\
\cline { 2 - 9 } & B & Std. Error & B & & & Tolerance & VIF \\
\hline Constant & -37513.604 & 17170.209 & & -2.185 & $0.031^{* *}$ & & \\
\hline High security cost & -5489.843 & 1308.103 & -0.250 & --4.197 & $0.000^{* * *}$ & 0.021 & 1.086 \\
\hline $\begin{array}{l}\text { Withdrawal from growing } \\
\text { certain crop }\end{array}$ & -9957.843 & 3758.682 & 0.248 & -2.649 & $0.009^{* *}$ & 0.371 & 2.696 \\
\hline Quitting farming activities & -8151.104 & 992.543 & 0.498 & --8.212 & $.000^{* * *}$ & 0.884 & 1.131 \\
\hline $\begin{array}{l}\text { Discourage adoption of } \\
\text { modern technologies }\end{array}$ & -1792.742 & 2066.687 & -0.052 & -0.867 & 0.387 & 0.909 & 1.100 \\
\hline Reduction in output & -5939.736 & 2121.276 & -0.250 & -2.800 & $0.006^{* *}$ & 0.409 & 2.443 \\
\hline
\end{tabular}

Dependent variable: income losses, $\mathrm{R}^{2}=0.580, \mathrm{D}=0.943, \mathrm{~F}=35.628,{ }^{* * *}$ Significant at $1 \% .{ }^{* *}$ Significant at $5 \%$

\section{Adaptation strategies of pilfering}

The result in Table 11 showed that most (78.5\%) of the respondents did not use any form of measure to curb the menace of pilfering on the farm, presumably depending upon God for divine intervention. The result further indicates that $61.5 \%$ and $35.6 \%$ of the respondents claimed to regularly and occasionally use charms and fence respectively. The least (25.1\%) of them used vigilante in their farms to prevent farm pilfering. This number is small, since the majority of farmers are low-income farmers. So they have no sufficient money to spend on farmland watchmen. Charms appears in line with Olusanya (1995) work that charms is the most effective measure for the prevention of pilferages in Ogun State. Kehinde et al. (2015) findings show that most of the farmers $(73.2 \%)$ employed fenced poles to secure theft's access to the farm.

Table 11. Adaptation strategies of pilfering on farms

\begin{tabular}{|l|l|l|}
\hline $\begin{array}{l}\text { Prevention } \\
\text { measures }\end{array}$ & $\begin{array}{l}\text { Frequency } \\
\text { (YES) }\end{array}$ & Frequency (NO) \\
\hline Fence & $48(35.6)$ & $87(64.4)$ \\
\hline Charms & $83(61.5)$ & $52(38.5)$ \\
\hline Vigilante & $34(25.1)$ & $66(74.9)$ \\
\hline No measures used & $106(78.5)$ & $29(21.5)$ \\
\hline
\end{tabular}

Figures in parenthesis are percentages

\section{CONCLUSION}

The result for the crops under study shows a pilfering index of $68 \%$. Plantain and maize, however, were highly pilfered. The percentage loss of plantain income due to pilfering was higher than for other crops. This was confirmed by the ANOVA, which shows that the income loss amongst the various crop types is statistically significant at $5 \%$. Pilfering has been influenced by age, farming experiences, education, farm size, household size, security, attractiveness, employees with high number of dependents and farm location. The findings showed that high cost of security, quitting farming activities, withdrawal from growing certain crops and reduction in output of the farm contributed to income loss. Conclusively, the main security measure adopted was charm while majority of them never use any prevention measure. Considering the findings, it is recommended that:

i. Farmers should also organize vigilance group in order to checkmate the activities of those who pilfers their crops.

ii. Government should provide credit to the farmers to enable them apply the best security measures because it is capital intensive.

iii. Government should provide vigilantes to secure the farming environment to encourage food security since their services cannot be easily afford.

iv. Farmers should be encourage to insure their farms to discourage quitting.

v. Government should help the farmers to provide modern technologies that affordable to secure their farms instead of the crude method of charms.

\section{Statement of Conflict of Interest}

Authors have declared no conflict of interest.

\section{REFERENCES}

Anderson KM, McCall M 2005. Farm pilfering in Australia; Australian Institute of Criminology: Canberra: Australian. Retrieved on 30th August, 2018 from: $w w w . a i c . g o v . a u / p u b l i c a t i o n s / c u r r e n t$ $\% 20$ series/cfi/101-120/cfi119.aspx. 
Anongoku CP, Obinne O, Daudu S 2008. A SocioEconomic Analysis of Livestock Pilferage in Rural and Urban Areas of Benue State, Nigeria. Journal of Social Sciences. 17(2): 169-172.

Anonguku I 2005. Incidence of Livestock Pilferage in Benue State. Unpublished M.Sc. Thesis in Extension. Department of Agricultural Extension and Communication, University of Agriculture, Makurdi, Benue State, 73 pp.

Arene CJ, Anyeaji RC 2010. Determinants of food security among households in Nsukka Metropolis of Enugu State, Nigeria. Pakistan Journal of Science, 30: 9-16.

Banwo A 1995. Pilferage and Food Availability: The Marketing perspective. Proceeding of the First National Seminar on Pilferage, pp. 121-130.

Barclay EM 2001. A review of related literature on agricultural pilfering. Institute for Rural Futures, University of New England, retrieved on 30 August, 2018 from: www.criminologyresearchcouncil.gov. $\mathrm{au} /$ reports/barclay.pdf

Barclay EM, Donnermeyer JF 2011. Pilfering and security on agricultural operations. Security Journal, 24:1-18.

Barclay EM, Donnermeyer JF, Doyle BP, Talary D 2001. Property pilfering victimization and pilfering prevention on farms. Report to the NSW Attorney General's Pilfering Prevention Division (Report No. 012). Armidale, New South Wales: Institute for Rural Futures, University of New England.

Bennett C 2016. Thieves find big returns, little risks on farmlands. FARM/JOURNAL AGWEB. https://www.agweb.com/crops.

Bignon V, Caroli E, Galbiati R 2017. Pilfering to Survive? Pilfering and Income Shocks in Nineteenth Century France. The Economic Journal, 127 (599):19-49.

Bunei EK, Rono JK, Chessa SR 2013. Factors influencing farm pilfering in Kenya: opinions and experiences of farmers. International Journal of Rural Criminology, 2(1):75-100.

Ceccato V. 2016. Rural pilfering and community safety, Abingdon, Oxon: Routledge.

Claudia B, Bainson PK 2016. The Effect of Pilfering on the Profitability of Small Businesses A Case Study on Shield Agro Chemical Company Ltd in Takoradi. European Journal of Business and Management, 8: 144-151.

Donnermeyer JF, Barclay EM, Mears DP 2011. Policing agricultural pilfering. In: Mawby, R.I. and R. Yarwood (eds.): Rural policing and policing the rural: A constable countryside. Farnham: Ashgate, pp.193-204.

Ebojei CO, Odekina FO., Mosimabale VO and Abdullahi AN 2011. Socio-economic factors predisposing farmers' produce to pilferage in Idah local government area of Kogi State, Nigeria. The Journal of Agricultural Sciences, 6(1):16-23.
Eze CC, Ibekwe UC, Onoh P, Nwajiuba CU 2006. Determinants of adoption of improved cassava production technologies among farmers in Enugu State of Nigeria. Global Approach to Extension Practice (GAEP). 2(1):37-44.

FafChamps M, Minten B 2003. Pilfering and rural poverty: result of a natural experiment. Proceeding of the 25th International Conference of Agricultural Economics (IAAE).

Gbigbi TM 2018. Socioeconomic Factors Influencing Access to Land Among Women Arable Crop Farmers in Ika North East LGA, Delta State, Nigeria. Ife Journal of Agriculture,30(1): 52-62

Gbigbi TM. 2011. Economic Efficiency of Smallholder Sweet Potato Producers in Delta State, Nigeria: a Case Study of Ughelli South Local Government Area. Research Journal of Agriculture and Biological Sciences, 7(2): 163-168.

Graham B 2010. Analysis of the state of praedial larceny in member states of CARICOM". A report presented to CARICOM Council of Ministers for Trade and Agriculture during the recently completed Ninth Annual Caribbean Agriculture Week on 9-15 October, 2011, Windsor Park, Dominica.

Grote U, Debaucher F 2016 Rural pilfering in developing countries: Theoretical framework, empirical findings, research needs, ZEF Working Paper Series, No. 148, University of Bonn, Center for Development Research (ZEF), Bonn.

Ibrahim FD, Oformata AO, Jirgi AJ, Oseghale AI, Bako RK 2017.Determinants of maize-based arable crop farmers productivity in Niger state, Nigeria. Conference Proceedings of The 18" Annual National Conference of The Nigerian Association Of Agricultural Economists Held Al Federal University of Agriculture, Abeokuta, Nigeria 16' 19th October, 2017

Inkoom DKB 2011. Utilization of irrigation facilities towards poverty reduction in the upper western region of Ghana. Journal of Sustainable Development in Africa, 13(2): 335- 350.

Jones J 2008. Farm pilfering on Anglesey: Local partner's and organizations. Views on the Issue, second report, January 2008. Retrieved on 30th August, 2018 fromhttp://www.aber.ac.uk/en/media/ jane-jones---second-report.pdf.

Kehinde EA, Uchechukwu CU, Mamuh P 2015.Effect of Cattle Rustling on Income Of Farmers in Benue State, Nigeria. Nigerian Journal of Rural Sociology $16(2): 78-83$

Lemchi J, Tshiunza M, Tenkovano A 2003. Factors driving the intensity and rate of cooking Banana adoption in Nigeria. Journal of Agriculture and Social Research. 3(2):135-166.

Lesotho-South Africa Fence.2013. Retrieved 30 08, 2018, from globalsecurity.org: http://www.global security._org/military/world/rsa/fence-lesotho.htm 
Louise Manning and Jan Mei Soon (2016). Food Safety, Food Fraud, and Food Defense: A Fast Evolving Literature. Journal of food science, 18(4):823-834.

Magubane T 2011. Stock pilfering spiraling out of control. Retrieved 30 08-2018 from Kwanalu: $\mathrm{http}: / / \mathrm{www} . \mathrm{kwanalu} . c o . z a / d e f a u l t . a s p ? a c t i o n=$ news $\& \mathrm{Id}=540$.

Manu IN, Andu WN, Tarla DN, Agharih WN 2014. Socio-economic effect of cattle theft on the pastoralists of the North West Region of Cameroon. Scholarly Journal of Agricultural Science 4(6):299305.

McCaghy CH, Capron TA, Jamieson J, Carey SH 2016. Deviant Behaviour Pilfering, Conflict, and Interest Groups. E-Book8th Edition. New York: Routledge,https:/doi.org/10.4324/9781315664323

McCall M 2003. Results from the 2001-02 National Farm pilfering Survey. Australian Institute of Criminology, Trends and Issues in Pilfering and Criminal Justice, No.266.

Mears DP, Scott ML, Bhati AS 2007. Opportunity theory and agricultural pilfering victimization. Rural Sociology, 72(2):151-184.

Mears DP, Scott ML, Bhati AS 2007. Policy, Theory, and Research Lessons from an Evaluation of an Agricultural Pilfering Prevention Program. Urban Institute, Justice Policy Center, Florida State University.https://www.ncjrs.gov/pdffiles1/nij/gran ts/ 217908.pdf (accessed August 2018).

Miltonian A 2016. Causes of crime. Retrieved 06/04/2019, from Scribd.com. http://www.scribd. com.

Miller L 2017. Psychological Theories of Criminal Behavior. In: Van Hasselt V., Bourke M. (eds) Handbook of Behavioral Criminology. Springer, Cham pp 43-62. https://doi.org/10.1007/978-3319-61625-4_4.

Müller GS 2016. Magnitude of Livestock Theft in Kwa Sani and Factors That Could Influence It. A Master's thesis in Disaster Management in the Disaster Management Training and Education Centre for Africa at the University of the Free State.

Odekina FO 2009. An assessment of effects of pilferage on arable crop farmers in Idah local government area of Kogi State, Nigeria. A thesis Submitted to the Post Graduate School, Ahmadu Bello University, Zaria in Partial Fulfillment of the Requirements for the Award of Master of Science in Agricultural Extension and Rural Sociology.

Ofuoku, AU, Emuh, FN. 2009. African rural women in agricultural and rural development: Challenges and opportunities. In Agbamu, J.U. (ed). Perspectives in agricultural extension and rural development. Owerri, Nigeria: Springfield Publishers Ltd. Pp. 348-360.

Ogunjimi SI 2001.Operational habits and health hazard in the use of chemicals among cocoa farmers in Osun and Edo States. Unpublished M.Sc. Thesis. OAU Ile-Ife.

Olubanjo OO 1995. Pilferage: Concept, Dimension and Likely Motivation and Effect on Private Agricultural Venture in Nigeria. Paper and Proceedings Presented at Ogun state University, Nigeria. November, 13-16.

Olusanya TP, Adefuye BO, Adekinmisi AA 1995. Causes and Effects of Pilferage in Livestock Enterprises. In: Proceedings of Pilferage on farms, Nigeria. Samfard Farm Foundation, pp. 49 - 54.

Olusanya TP 1995. Causes, Method, Effects and Control of Pilfering in Livestock Enterprises in Ijebu North Local Government Area of Ogun State. Unpublished M.Sc. Thesis. Department of Agricultural Extension and Rural Sociology, Ogun State University, Ago-Iwoye, Ogun State, 84pp.

Oni OA, Fashogbon AE, 2013. Food poverty and livelihoods issues in rural Nigeria. African Journal of Agricultural and Resource Economics, 8: 108-135.

Osborn E 2015. Examining Macro-Level Correlates of Farm Equipment Pilfering: A Test of Routine Activity Theory and Social Disorganization Theory, PhD-dissertation, University of Louisville, Louisville, Kentucky Available online at http://ir.library.louisville.edu/etd/2248?utm_source =ir.library.louisville.edu\%2Fetd\%2F2248 \&utm_medium=PDF\&utm_campaign=PDFCoverP ages (retrieved on 16th October, 2019).

Palmary I 2001. Social Crime Prevention in South Africa's Major Cities. Retrieved 04/06/2019, from CSVR organization: http://www.csvr.org.za/docs/ urbansafety/socialcrimeprevention.pdf.

Prakash, D., 2003. Rural women, food security and agricultural cooperatives. A report presented to the Rural Development and Management Centre Kalkaji, New Delhi, 1-15.

Sabo BB, Isah SD, Chamo AM, Rabiu MA 2017. Role of Smallholder Farmers in Nigeria's Food Security. Scholarly Journal of Agricultural Science 7(1): 1-5.

Swanson CR, Chamelin NC, Territo L 2001.Criminal investigation. Boston: McGraw Hill.

Van Kesteren J, van Dijk J, Mayhew P 2014. The international pilfering victim's surveys: A retrospective, International Review of Victimology, 20(1): 49-69.

Vincent B, Eve C,Roberto G 2014. Stealing to Survive? Crime and Income Shocks in 19th Century France. IZA Discussion Paper No. 8531.

Yahaya MK 2007. Communication and Social Change: Lesson from Cassava Technology Transfer in Nigeria. Journal of Agricultural Extension 10: 178.

Zalkuwi J, Yusuf C, Ibrahim A, 2014. Analysis of cost and return in cowpea production in Adamawa State, Nigeria. The International Journal of Humanities and Social Studies, 11(2): 144-147. 